\title{
Lingua Villosa Nigra Associated with the Use of Electronic Cigarette
}

\author{
Lingua Villosa Nigra Associada ao Uso de Cigarro Electrónico
}

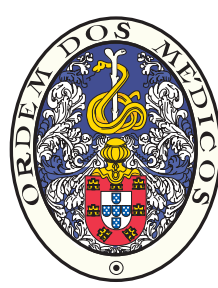

Keywords: Smoking; Tobacco Products; Tongue, Hairy.

Palavras-chave: Hábito de Fumar; Língua Pilosa; Produtos do Tabaco.

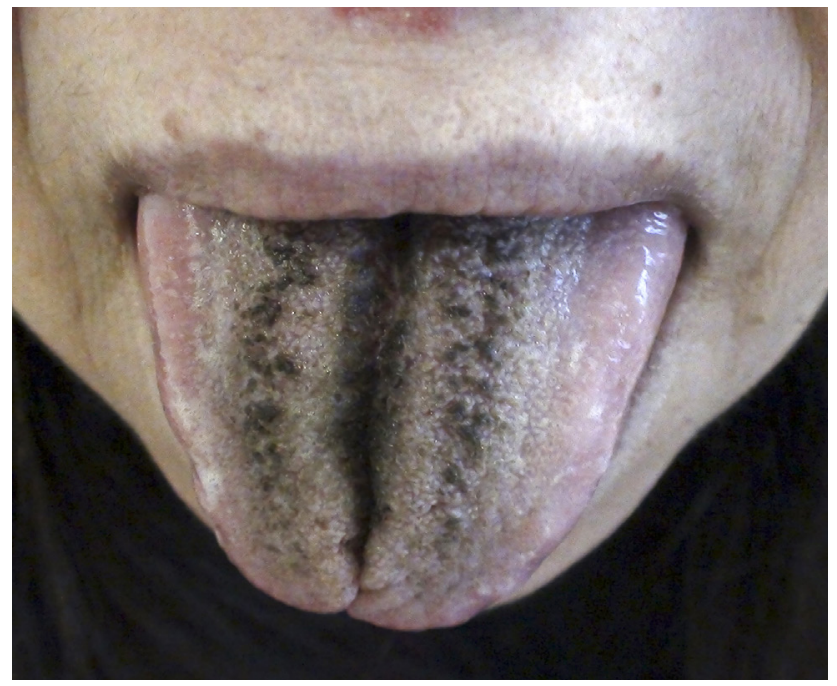

Figure 1 - Lingua villosa nigra

A 66-year old female patient presented to her family physician an asymptomatic black discoloration of the tongue she noted that day (Fig. 1). There was no other sign associated. The case was presented to another family physician and the diagnosis of lingua villosa nigra ${ }^{1-5}$ was established. This patient was a hard smoker and coffee drinker, with hypertension and history of depression. She had stopped tobacco smoking and initiated electronic cigarette a few weeks before. After that, when she stopped using the electronic cigarette and started tobacco cigarette,

\section{REFERENCES}

1. Yan P, Mistry N, Au S. Dermacase. Can you identify this condition? Black hairy tongue. Can Fam Physician. 2010;56:439-41

2. Dimitrios $S$, Maria-Aikaterini $P$, Alexandre $F$, Nikolaus $S$. Lingua villosa nigra. Intern Med. 2012;51:1453

3. Vañó-Galván D, Jaén P. Black hairy tongue. Cleve Clin J Med

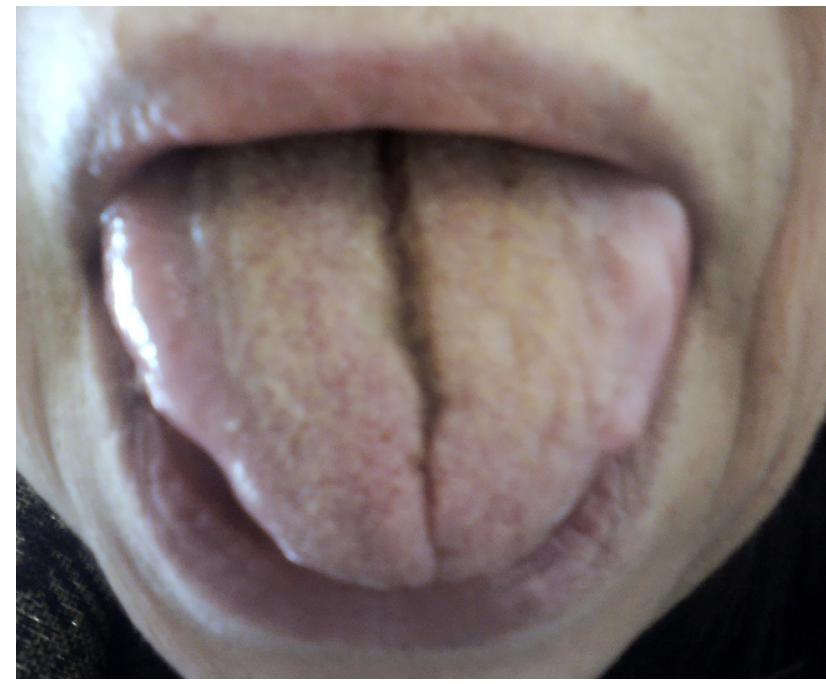

Figure 2 - Disappearance of lingua villosa nigra after electronic cigarette discontinuation

the lesions started disappearing spontaneously in less than one week (Fig. 2). The lesions worsened when she began using electronic cigarette again.

Lingua villosa nigra is a benign condition associated with some antibiotics, bad oral hygiene, age, smoking, alcohol and coffee drinking, cancer or HIV patients. ${ }^{1-4}$ Chromogenic pathogens (e.g., C. albicans) are sometimes implicated. ${ }^{1-3,5}$ We did not found any previously relationship with electronic cigarette reported.

2008;75:847-8

4. Perrin E, Ota KS. Tongue lesion with sensation of fullness in the mouth. Am Fam Physician. 2011;83:839-40.

5. Ramsakal A, Mangat L. Lingua villosa nigra. N Engl J Med. 2007;357:2388.

\footnotetext{
1. Unidade de Saúde Familiar Auren. Agrupamento de Centros de Saúde Médio Tejo. Ourém. Portugal.

$\bowtie$ Autor correspondente: Helder Farinha. helderfarinha.saude@gmail.com

Recebido: 25 de Maio de 2014 - Aceite: 04 de Agosto de 2014 | Copyright () Ordem dos Médicos 2014
} 
Helder FARINHA, Vera MARTINS

\section{Lingua Villosa Nigra Associated with the Use of Electronic Cigarette}

Acta Med Port 2015:28:393-393

Publicado pela Acta Médica Portuguesa, a Revista Científica da Ordem dos Médicos

Av. Almirante Gago Coutinho, 151

1749-084 Lisboa, Portugal.

Tel: +351218428215

E-mail: submissao@actamedicaportuguesa.com

www.actamedicaportuguesa.com

ISSN:0870-399X | e-ISSN: 1646-0758

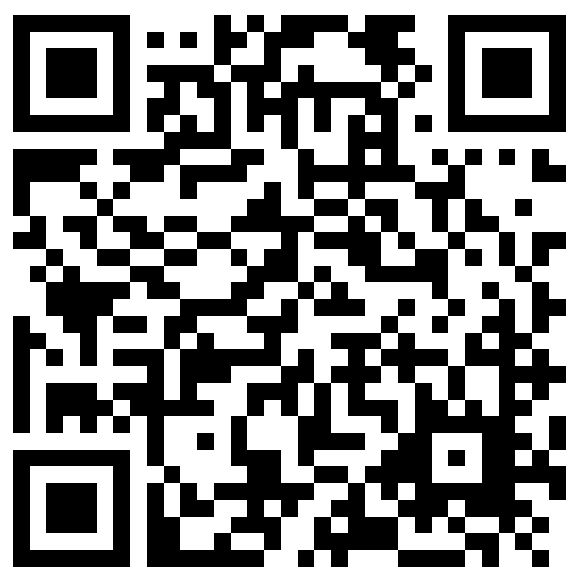

